\title{
Effect of RNAi-mediated silencing of Livin gene on biological properties of colon cancer cell line LoVo
}

\author{
A.M. Zou ${ }^{1 *}$, H.F. Wang ${ }^{2 *}$, W.F. Zhu ${ }^{1}$, F.X. Wang ${ }^{1}$ and J.J. Shen ${ }^{3}$ \\ ${ }^{1}$ Department of Clinical Laboratory, Changan Hospital, Xi'an, China \\ ${ }^{2}$ Department of Clinical Laboratory, Xi' an Central Hospital, Xi'an, China \\ ${ }^{3}$ Department of Clinical Laboratory, Tangdu Hospital, Fourth Military Medical \\ University, Xi'an, China \\ *These authors contributed equally to this study. \\ Corresponding author: J.J. Shen \\ E-mail: jianjunshencn@yeah.net
}

Genet. Mol. Res. 13 (2): 3832-3841 (2014)

Received July 24, 2013

Accepted December 6, 2013

Published May 16, 2014

DOI http://dx.doi.org/10.4238/2014.May.16.8

\begin{abstract}
This study aimed to investigate the effect of RNAimediated silencing of the Livin gene on biological properties of the colon cancer cell line LoVo. Interference vectors pSilencer4.1-L1 and pSilencer4.1-L2 targeting the Livin gene were constructed and transfected into LoVo cells. The expression of the Livin gene was determined by RT-PCR and Western blotting. The apoptosis, cell cycle, colony formation, proliferation of LoVo cells, as well as their sensitivity to cisplatin, were detected by flow cytometry, colony formation assay and MTT. Livin mRNA and protein expression in LoVo cells could be effectively silenced by pSilencer4.1-L1 but not pSilencer4.1-L2. In the pSilencer4.1-L1 transfection group, the apoptosis rate of LoVo cells was significantly higher than in the control group (24.2 \pm 3.2 vs $8.1 \pm 1.4 \%$, $\mathrm{P}<0.01$ ), and after $72 \mathrm{~h}$, cell proliferation was clearly decreased (about $70 \%$ inhibition). Compared with the control group, the colony formation rate in pSilencer4.1-Ll transfection group was obviously decreased (15
\end{abstract}


\pm 4.6 vs $85 \pm 5.8 \%, \mathrm{P}<0.01)$, with increased proportion of $\mathrm{S}$ phase cells (45.7 \pm 4.9 vs $28.0 \pm 3.0 \%, \mathrm{P}<0.01$ ), decreased proportion of G1 phase cells $(43.0 \pm 5.2$ vs $62.8 \pm 5.1 \%, \mathrm{P}<0.01)$, and increased sensitivity to cisplatin (apoptosis rate increased from $43.4 \pm 6.9$ to $65.3 \pm 6.2 \%, \mathrm{P}<$ 0.01). pSilencer4.1-Ll can effectively silence Livin gene expression in LoVo colon cancer cells, inhibit cell proliferation and colony formation, induce apoptosis, and enhance sensitivity to cisplatin.

Key words: Livin gene; Silencing; Biological properties; LoVo

\section{INTRODUCTION}

Colon cancer is one of the most common malignancies worldwide and has shown increased incidence, especially in developing countries (Shen et al., 2009). Until recently, a major treatment strategy for early cancer has been surgical resection, which shows good outcome over other treatments. But the treatment results for metastatic disease are still unsatisfactory with surgery alone. In these cases, clinicians consider other treatment options such as chemotherapeutic agents and targeted agents.

Livin (BIRC7) is a recently identified member of the inhibitor of apoptosis protein (IAP) family that suppresses apoptosis induced by multiple stimuli. Livin contains molecular features (BIR and RING domains) characteristic of IAP proteins; in particular, the BIR domain appears to mediate inhibition of cell death proteases, such as caspases 3, 7, and 9. This antiapoptotic function is believed to be important in protecting livin-expressing tumor cells after chemotherapy (Liu et al., 2007; Wang et al., 2008; Yan, 2011).

Several investigators have reported livin expression in fetal and some tumor cell lines and primary tumors (Augello et al., 2009; Dasgupta et al., 2010; El-Mesallamy et al., 2011). Kasof and Gomes (2001) reported high expression of the $\alpha$-isoform in several melanoma cell lines and primary melanoma tumors. Similarly, Vucic et al. (2000) identified high expression of the $\alpha$ - and $\beta$-isoforms in a number of melanoma lines and termed this protein ML-IAP or melanoma IAP; these lines were more resistant to several chemotherapeutic agents compared with lines expressing lower levels of the protein. Ashhab et al. (2001) showed that Livin $\alpha$, but not Livin $\beta$, protected cells from staurosporine-induced apoptosis, whereas apoptosis upon etoposide treatment was blocked only by the Livin $\beta$-isoform. These conflicting results may be explained, at least in part, by differences in the Livin levels upon ectopic overexpression and by the different cellular backgrounds examined. In contrast to overexpression analyses, RNAi technology allows a functional analysis by specifically manipulating endogenous livin gene expression directly within Livin-expressing tumor cells (Crnkovic-Mertens et al., 2003, 2006). Livin-overexpressing cells are more resistant to apoptotic stimuli than normal cells (Wang et al., 2010; Ding et al., 2013; Li et al., 2013). Thus, Livin intervention contributes to the apoptosis of cancer cells, making it an attractive target for cancer treatment.

In this study, livin-targeted siRNA expression vectors were constructed and the colon cancer cell line LoVo was transfected with the vector-based siRNA. Next, the biological effects of livin knockdown on cell chemosensitivity and tumorigenicity were determined in vitro. These experiments provide an important foundation for understanding the function of Livin and gene therapy of human colon cancer. 


\section{MATERIAL AND METHODS}

\section{Cell culture}

Human colon carcinoma cell line LoVo was cultured in RPMI 1640 medium with $10 \%$ fetal bovine serum (FBS), $0.3 \mathrm{mg} / \mathrm{mL}$ glutamine, $100 \mathrm{U} / \mathrm{mL}$ penicillin, and $100 \mu \mathrm{g} / \mathrm{mL}$ streptomycin at $37^{\circ} \mathrm{C}$ in a humidified $5 \% \mathrm{CO}_{2}$ incubator.

\section{Construction of plasmids expressing various shRNA}

Two different livin-specific siRNAs (L1: tcttccacacaggccatca, L2: gagactttgtccacagtgt) were designed using the siRNA target finder tool (http://www.ambion.com/techlib/ misc/siRNA_finder.html). A BLAST search (http://www.ncbi.nlm.nih.gov/BLAST) using the selected siRNA sequences was performed to ensure that only a single gene was targeted. shRNAs were chemically synthesized by Shanghai Sangon Biological Co. (China). Each shRNA was flanked by BamHI and HindIII sites to facilitate cloning. Vectors were designated pSilencer4.1-L1, pSilencer4.1-L2. The pSilencer4.1-CMV neo negative control vector encodes an shRNA with no significant homology to any known human mRNA and was used as a negative control.

\section{Transfection of shRNA expression vectors in LoVo cells}

Before transfection, $1.0 \times 10^{5}$ cells were seeded in each well of 6-well plates containing culture medium. Prior to transfection, medium was replaced with serum-and antibiotic-free medium. LoVo cells at $90-95 \%$ confluence were transfected as follows. Serum-free DMEM $(250 \mu \mathrm{L})$ containing $2 \mu \mathrm{g}$ plasmid was mixed with $250 \mu \mathrm{L}$ serum-free DMEM containing $5 \mu \mathrm{L}$ Lipofectamine 2000 reagent and was incubated at room temperature. The DNA/Lipofectamine 2000 mixture was added to each well within $45 \mathrm{~min}$. Plates were then incubated at $37^{\circ} \mathrm{C}$ for 4 $\mathrm{h}$, after which $500 \mu \mathrm{L}$ FBS were added to each well. Cells were then grown for an additional 24 to $48 \mathrm{~h}$ at $37^{\circ} \mathrm{C}$ before further analysis. The efficiency of transfection was determined by pEGFP-N2 vectors, which parallel transfection with pSilencer4.1-L2 and pSilencer4.1-CMV neo plasmid and assessed by immunofluorescence microscopy.

\section{RNA preparation and RT-PCR}

RNA was isolated from LoVo cells using Trizol according to manufacturer instructions (Invitrogen Carlsbad, USA). Total RNA $(1.0 \mu \mathrm{g})$ was reverse-transcribed to cDNA using reverse transcriptase (Invitrogen Carlsbad). The resulting cDNA was PCR amplified using livin-specific primers (sense primer 5'-tgaggagttgcgtctggc-3', antisense primer 5'-gcacggcacaaagac gat-3', 502-bp product). A 353-bp fragment of $\beta$-actin was amplified and served as an internal standard, using sense primer $5^{\prime}$-gctcgtcgtcgacaac ggctc-3', antisense primer $5^{\prime}$-caaacatgatctgggtcatcttctc-3'. Cycling conditions were as follows: $95^{\circ} \mathrm{C}$ for $2 \mathrm{~min}$ and then 30 cycles of $95^{\circ} \mathrm{C}$ for $1 \mathrm{~min}, 58^{\circ} \mathrm{C}$ for $30 \mathrm{~s}$ and $72^{\circ} \mathrm{C}$ for $30 \mathrm{~s}$, and finally $72^{\circ} \mathrm{C}$ for 5 min. PCR products were quantified using an M-26-UVP image analysis system and the Labworks4.5 system software (USA). The level of Livin was normalized to that of $\beta$-actin. 


\section{Western blot analysis}

Cells were washed with PBS and lysed at $4{ }^{\circ} \mathrm{C}$ for $30 \mathrm{~min}$ in PBS containing $50 \mathrm{mM}$ Tris- $\mathrm{HCl}, \mathrm{pH} 7.4,150 \mathrm{mM} \mathrm{NaCl}, 1.0 \%$ Triton X-100, 0.1\% SDS, $10 \%$ glycerin, and $1.0 \mathrm{mM}$ phenylmethylsulfonyl fluoride). Cell extracts were cleared by centrifugation at 12,000 $g$ for 20 min at $4^{\circ} \mathrm{C}$, and supernatants were used for Western blot analysis. Up to $300 \mu \mathrm{g}$ total protein (quantitated by UV spectrophotometer) from each sample was heated at $95^{\circ} \mathrm{C}$ for $5 \mathrm{~min}$ after mixing with an equal volume of 2 X SDS loading buffer. Samples were separated on $15 \%$ polyacrylamide gels and then electrotransferred onto nitrocellulose $(0.45 \mu \mathrm{m})$. Membranes were blocked in PBS with 5\% skim milk and then incubated overnight with primary antibody specific for livin at $4^{\circ} \mathrm{C}$. Membranes were then incubated with peroxidase-linked secondary antibodies at $37^{\circ} \mathrm{C} 1 \mathrm{~h}$. Western blots were visualized using $0.1 \mathrm{mg} / \mathrm{mL}$ diaminobenzidine in $\mathrm{H}_{2} \mathrm{O}_{2}$. Anti- $\beta$-actin monoclonal antibodies were used on each blot to ensure equal loading of protein. Band intensities were quantified as described above.

\section{Evaluation of apoptosis}

At $48 \mathrm{~h}$ after transfection, cells were fixed in 70\% ethanol, stained using theAnnexin V-FITC apoptosis assay kit (Becton Dickinson, USA) according to the instruction manual, and analyzed with a FACSCalibur flow cytometer (Becton Dickinson). For evaluation of apoptosis induced by cisplatin, cells were treated with $5.0 \mu \mathrm{g} / \mathrm{mL}$ cisplatinin culture medium 48 hafter transfection and then grown for an additional $48 \mathrm{~h}$ at $37^{\circ} \mathrm{C}$. Cells were then harvested and analyzed as described above.

\section{Proliferation assay}

Proliferation was measured by the MTT [3-(4,5-dimethylthiazol-2-yl)2,5-diphenyl tetrazolium bromide] assay. At 24 hours after transfection, cells were harvested and $2 \mathrm{x}$ $10^{4}$ cells were seeded in wells of 24-well plates in culture medium. At each time point, absorbance (A) was measured at $490 \mathrm{~nm}$ using a microplate reader (Becton Dickinson). For evaluation of cell proliferation after cisplatin treatment, LoVo cells were treated $5.0 \mu \mathrm{g} /$ $\mathrm{mL}$ cisplatinin culture medium $48 \mathrm{~h}$ after transfection with shRNAs, and then grown for an additional $96 \mathrm{~h}$ at $37^{\circ} \mathrm{C}$. At each time point, absorbance (A) was measured as described above.

\section{Cell cycle analysis}

At $48 \mathrm{~h}$ after transfection, cells were stained using the Cycle TEST ${ }^{\mathrm{TM}}$ PLUS DNA cell cycle assay kit (Becton Dickinson) and analyzed by FACSCalibur flow cytometer (Becton Dickinson). Data were analyzed using the CellQuest software.

\section{Colony formation assay}

Cells were transfected with individual pSilencer4.1-L1 and pSilencer4.1-L2. The pSilencer4.1-CMV-neo was the negative control vector. Two hundred cells were seeded in 30- 
mm Petri dishes and cultured for 10 days. The colonies were counted under a microscope and colony formation rates were calculated and recorded photographically.

\title{
Statistical analysis
}

Data are reported as means \pm SD. Statistical significance was determined by the analysis of variance and SNK-q test. $\mathrm{P}<0.05$ was considered to be statistically significant.

\section{RESULTS}

\section{Silencing of livin by RNAi to inhibit cell proliferation and enhance chemosensitiv- ity of LoVo cells}

To investigate the function of livin in colon carcinoma, we investigated the consequences of livin knockdown in colon carcinoma cells by RNAi. Silencing of livin by vectorbased RNAi decreased cell proliferation and increased apoptosis in LoVo. On the basis of GFP expression from a control vector, transfection efficiency was over $75 \%$ for this cell line. One livin shRNA (pSilencer4.1-L1) knocked down livin expression at both the mRNA and protein levels, as assessed by RT-PCR and Western blot analyses (Figure 1A, B). In addition, after knockdown the apoptotic index of LoVo cells increased $15 \%$, while the rate of proliferation decreased, and the cell number decreased about $40 \%$ compared with control groups (Figure 2A, B). The number of cells in the $\mathrm{S}$ phase of the cell cycle increased by $20 \%$, while the number of cells in G1 phase decreased about 20\% (Figure 3). After LoVo cells were treated with cisplatin, the survival rate of LoVo cells transfected with pSilencer4.1-L1 vectors decreased 50\%, while apoptotic index increased about 20\%, compared with control groups (Figures 4 and 5).

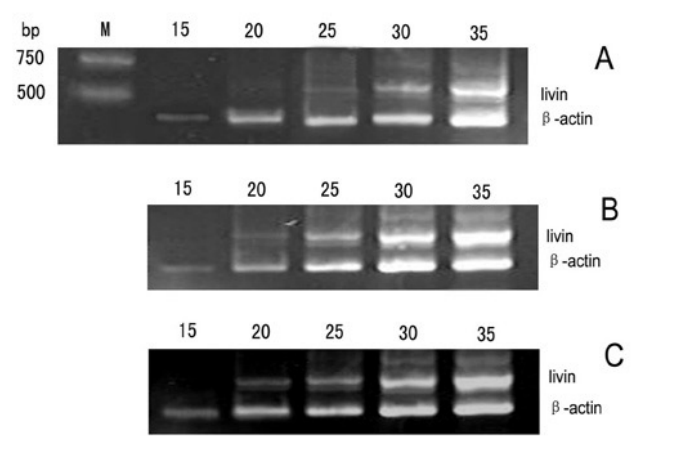

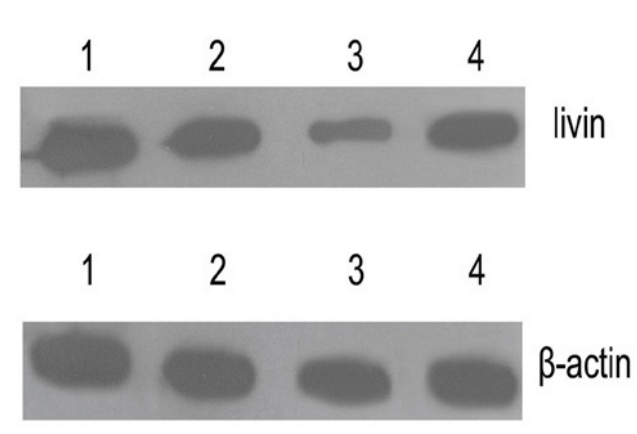

\begin{abstract}
A
B

Figure 1. Knockdown of livin by vector-based RNAi in LoVo cells. A. Semiquantitative RT-PCR analysis of livin mRNA in LoVo cells $24 \mathrm{~h}$ after transfection with shRNA expression plasmids. A = pSilencer4.1-L1-transfected, B= pSilencer4.1-L2-transfected C $=$ pSilencer3.1- negative control-transfected; B. Western blot analysis of livin protein in LoVo cells $72 \mathrm{~h}$ after transfection with shRNA expression plasmids. Lane $1=$ untransfected, lane $2=$ pSilencer3.1neative control-transfected, lane $3=$ pSilencer4.1-L1-transfected, lane $4=$ pSilencer4.1-L2, transfected.
\end{abstract}


A

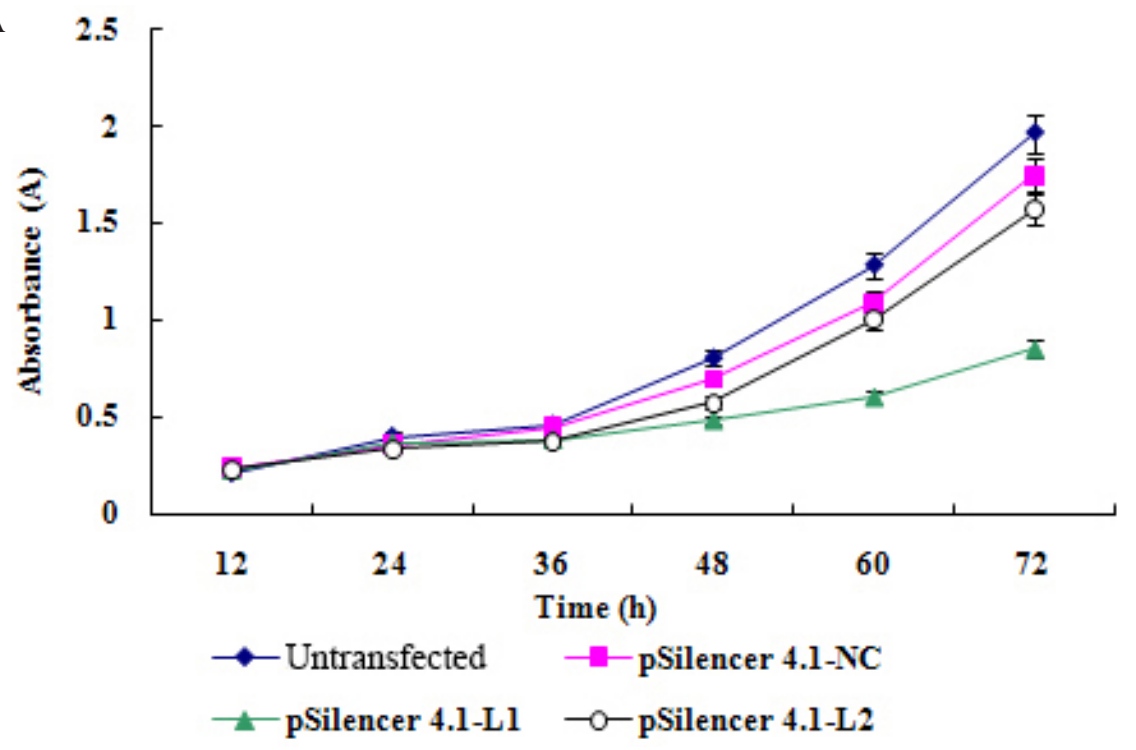

B

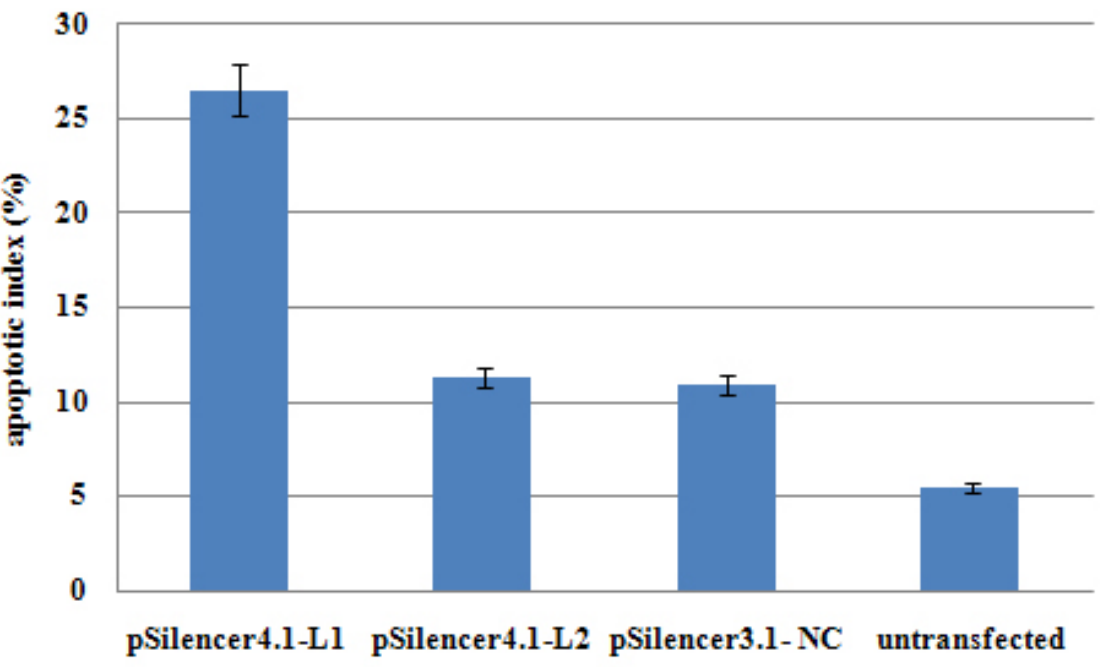

Figure 2. A. Growth curve of LoVo cells after transfection with shRNA expression plasmids. B. Apoptosis index of PC3 cells transfected with siRNA expression vector.

\section{Knockdown of livin in colon carcinoma cells inhibits colony formation}

The LoVo cells transfected with pSilencer-L1 cells formed fewer colonies compared to the control cells. The colony formation rate of LoVo cells transfected with pSilencer-L1 cells was only $15 \pm 4.6 \%$. In comparison, the colony formation rates for LoVo cells transfected with pSilencer4.1-CMV neo negative control and pSilencer-L2 were $85 \pm 5.8$ and $54 \pm 7.5 \%$, respectively. The colony formation rate of LoVo cells transfected by the pSilencer-L1 gene 
was significantly lower than that of parental LoVo cells $(\mathrm{P}<0.01)$ and LOVO cells transfected with pSilencer4. 1-CMV neo negative control $(\mathrm{P}<0.01)$, suggesting that $\mathrm{pSilencer-L1}$ expression inhibits the growth of LoVo cells (Figure 6).

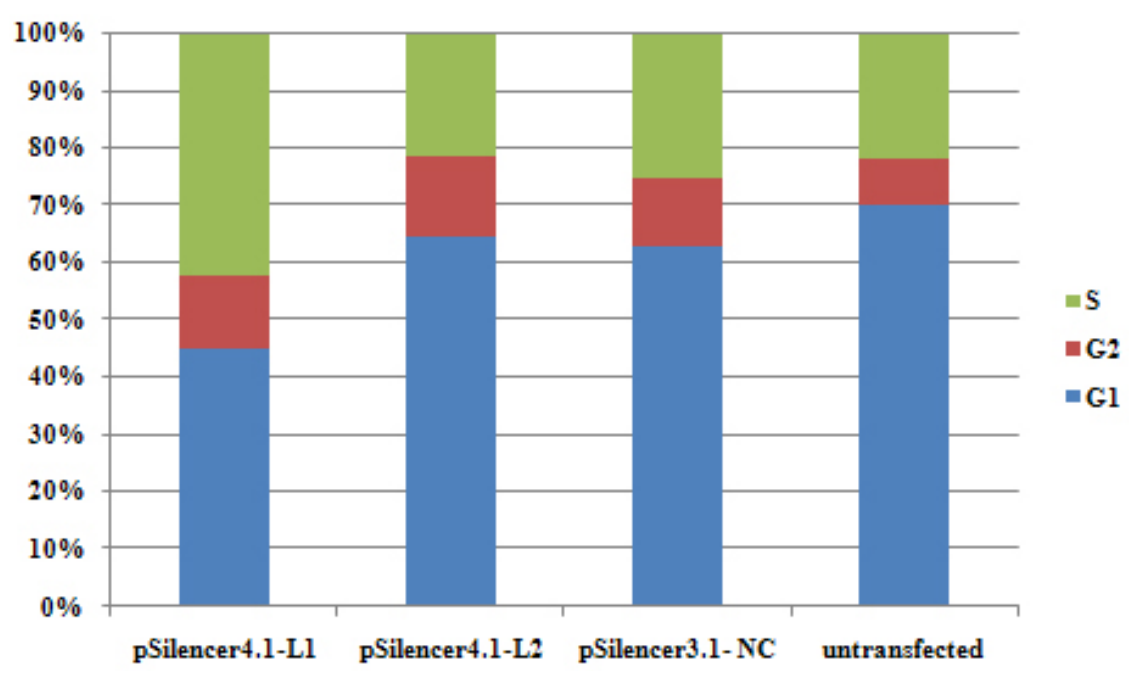

Figure 3. Cell cycle analysis of LoVo cells following siRNA expression plasmid transfection.
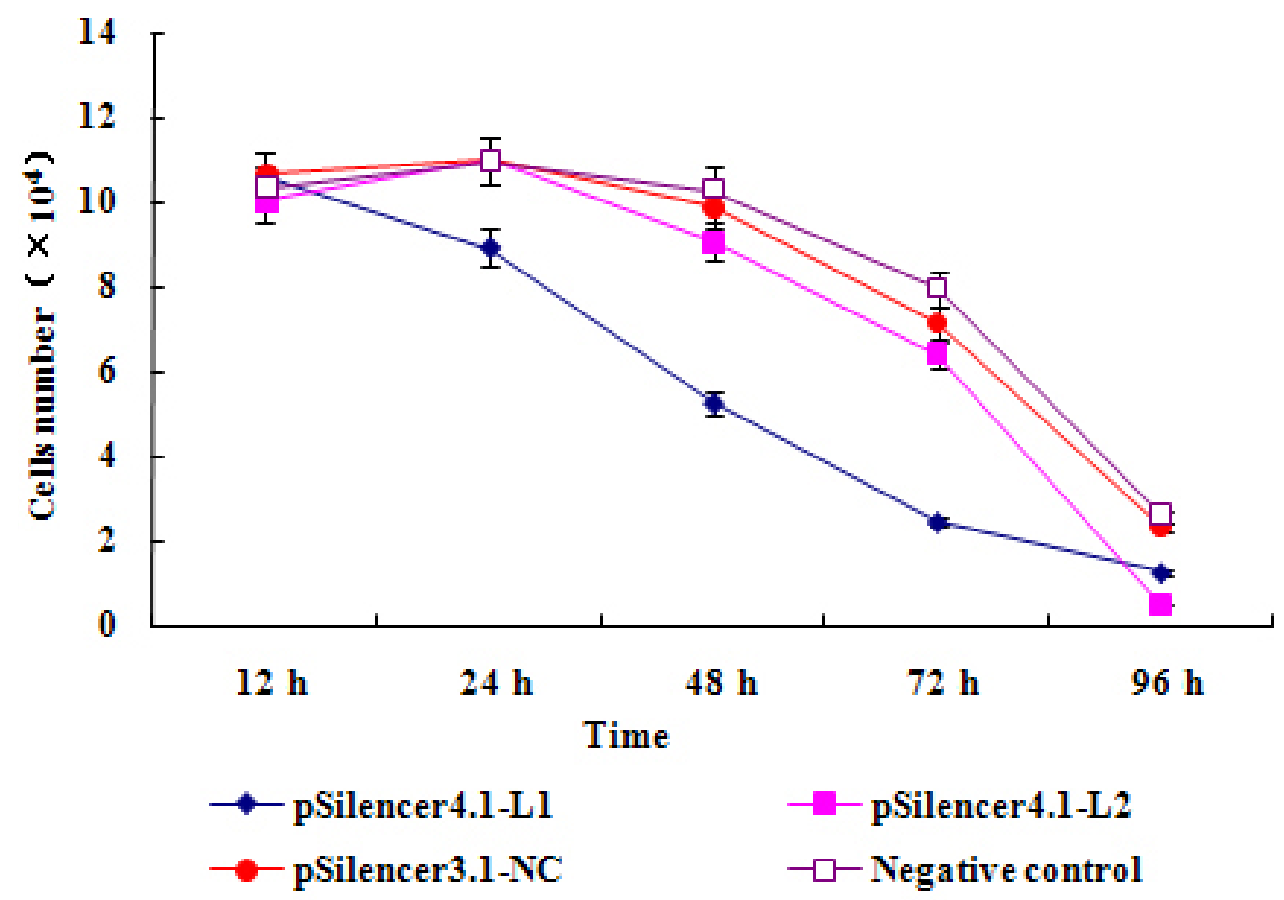

Figure 4. Survival curve of LoVo cells after transfection with shRNA expression plasmids and platinol treatment. 


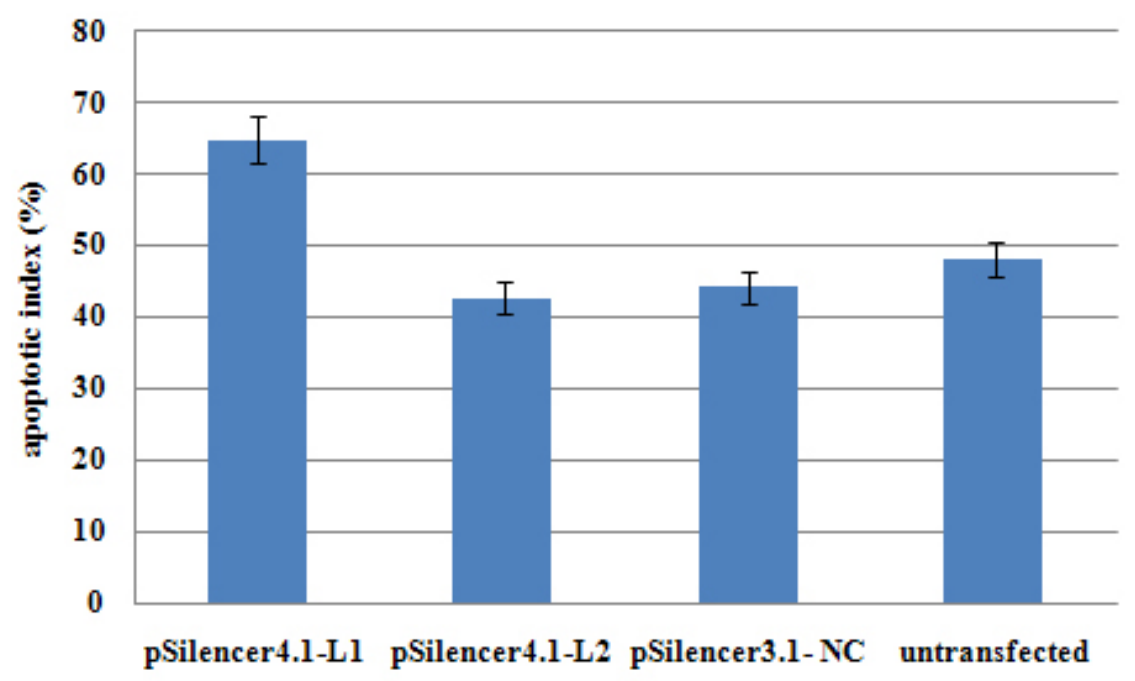

Figure 5. Apoptosis index of $\mathrm{PC} 3$ cells transfected with siRNA expression vector and platinol treatment.

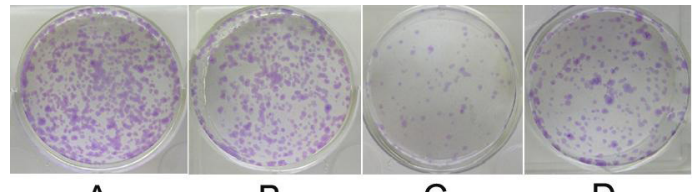

A

B

C

D

Figure 6. Colony formation assay of LoVo cells transfected with pSilencer4.1-CMV neo negative control (A); LoVo cells transfected with pSilencer-L1 (B); LoVo cells transfected with pSilencer-L2 and grown for 7-10 days in the presence of Geniticin to select for stable transfectants $(\mathbf{C})$; parallel cells $(\mathbf{D})$. Colonies were fixed with formaldehyde and stained with crystal violet.

\section{DISCUSSION}

Inhibitors of apoptosis (IAPs) are a class of evolutionarily conserved proteins whose homologs were initially identified in baculoviruses as a mechanism of preventing host cells from death after viral infection. Several members of the family are currently known in humans, namely NAIP, cIAP1/2, Apollon/Bruce, ILP2, XIAP, survivin and livin. All IAPs share up to three conserved zinc-binding baculovirus IAP repeat (BIR) domains, each about 70 amino acids in length. Almost every BIR domain possesses a groove for proteins with the IAPbinding motif that was identified in the caspases, Smac and HtrA2/Omi (Yan, 2011; Hartman and Czyz, 2013).

Livin is an important member of IAPs, and the anti-apoptotic activity of Livin is mediated through the inhibition of caspase-3, -7, and -9, as well as by its E3 ubiquitin-ligase-like activity, which promotes the degradation of all IAPs (Ma et al., 2006; Chang and Schimmer, 2007). Livin can inhibit initiator caspase-9, but caspase-9 and -8 cannot cleave Livin. Thus, Livin is able to interfere with the apoptotic process immediately at the starting point. The situa- 
tion changes, however, once a sufficient apoptotic signal is received, when the effector caspases such as $-3,-6$, and -7 are then activated, and the cell is committed to apoptosis. Caspase- 3 and -7 are also inhibited by Livin (Kasof and Gomes, 2001), at the same time, they are able to cleave Livin and convert it from an antiapoptotic agent to a proapoptotic agent (Nachmias et al., 2003).

Livin-overexpressing cells are more resistant to apoptotic stimuli than are normal cells (Wang et al., 2010; Ding et al., 2013; Li et al., 2013). Thus, Livin intervention contributes to the apoptosis of cancer cells, making Livin an attractive target for cancer treatment.

RNA interference (RNAi) is a genetic interference phenomenon directed by doublestranded RNA. RNAi specifically and efficiently degrades homogeneous mRNA, resulting in post-transcriptional gene silencing (Fire et al., 1998; Zamore, 2001). Since its discovery in 1998, RNAi has been rapidly developed into one of the most widely applied technologies with therapeutic potential in molecular and cellular research.

The livin gene is also susceptible to efficient and specific silencing by using siRNA technology. Livin silencing is associated with caspase- 3 activation and strongly increases the apoptotic rate in response to different pro-apoptotic stimuli, suggesting that Livin may be a critical determinant for tumorigenesis. Thus, Livin silencing has been explored as a novel therapeutic strategy to chemosensitize human tumor cells (Wang et al., 2008; Yuan et al., 2012).

In this study, we examined the consequences of livin knockdown using two different livin shRNA expression vectors. Livin knockdown in LoVo cells led to an increased apoptotic index, decreased proliferation, and decreased cell number. In addition, the number of cells in the G2 and S phase of the cell cycle increased, while the number in G1 phase decreased. After cisplatin treatment, the survival rate of LoVo cells transfected with livin shRNA expression vectors decreased about 50\%, and apoptotic index increased $23.7 \%$. Together, these results suggest that livin knockdown suppresses LoVo cells proliferation and blocks LoVo cells in the G2 and S phase. Livin knockdown also enhanced the sensitivity of LoVo cells to cisplatin.

In summary, the study provides a model for the study of livin function in colon carcinoma and indicates that livin may be a new gene therapy target for colon carcinoma.

\section{REFERENCES}

Ashhab Y, Alian A, Polliack A, Panet A, et al. (2001). Two splicing variants of a new inhibitor of apoptosis gene with different biological properties and tissue distribution pattern. FEBS Lett. 495: 56-60.

Augello C, Caruso L, Maggioni M, Donadon M, et al. (2009). Inhibitors of apoptosis proteins (IAPs) expression and their prognostic significance in hepatocellular carcinoma. BMC Cancer 9: 125.

Chang $\mathrm{H}$ and Schimmer AD (2007). Livin/melanoma inhibitor of apoptosis protein as a potential therapeutic target for the treatment of malignancy. Mol. Cancer Ther. 6: 24-30.

Crnkovic-Mertens I, Hoppe-Seyler F and Butz K (2003). Induction of apoptosis in tumor cells by siRNA-mediated silencing of the livin/ML-IAP/KIAP gene. Oncogene 22: 8330-8336.

Crnkovic-Mertens I, Semzow J, Hoppe-Seyler F and Butz K (2006). Isoform-specific silencing of the Livin gene by RNA interference defines Livin beta as key mediator of apoptosis inhibition in HeLa cells. J. Mol. Med. 84: 232-240.

Dasgupta A, Alvarado CS, Xu Z and Findley HW (2010). Expression and functional role of inhibitor-of-apoptosis protein livin (BIRC7) in neuroblastoma. Biochem. Biophys. Res. Commun. 400: 53-59.

Ding ZY, Liu GH, Olsson B and Sun XF (2013). Upregulation of the antiapoptotic factor Livin contributes to cisplatin resistance in colon cancer cells. Tumour. Biol. 34: 683-693.

El-Mesallamy HO, Hegab HM and Kamal AM (2011). Expression of inhibitor of apoptosis protein (IAP) livin/BIRC7 in acute leukemia in adults: correlation with prognostic factors and outcome. Leuk. Res. 35: 1616-1622.

Fire A, Xu S, Montgomery MK, Kostas SA, et al. (1998). Potent and specific genetic interference by double-stranded RNA in Caenorhabditis elegans. Nature 391: 806-811.

Hartman ML and Czyz M (2013). Anti-apoptotic proteins on guard of melanoma cell survival. Cancer Lett. 331: 24-34.

Genetics and Molecular Research 13 (2): 3832-3841 (2014)

CFUNPEC-RP www.funpecrp.com.br 
Kasof GM and Gomes BC (2001). Livin, a novel inhibitor of apoptosis protein family member. J. Biol. Chem. 276: 32383246.

Li X, Fan S, Li L, Wang L, et al. (2013). RNA interference-mediated knockdown of Livin suppresses cell proliferation and invasion and enhances the chemosensitivity to cisplatin in human osteosarcoma cells. Int. J. Oncol. 43: 159-168.

Liu B, Han M, Wen JK and Wang L (2007). Livin/ML-IAP as a new target for cancer treatment. Cancer Lett. 250: 168176.

Ma L, Huang Y, Song Z, Feng S, et al. (2006). Livin promotes Smac/DIABLO degradation by ubiquitin-proteasome pathway. Cell Death Differ. 13: 2079-2088.

Nachmias B, Ashhab Y, Bucholtz V, Drize O, et al. (2003). Caspase-mediated cleavage converts Livin from an antiapoptotic to a proapoptotic factor: implications for drug-resistant melanoma. Cancer Res. 63: 6340-6349.

Shen W, Wang CY, Wang XH and Fu ZX (2009). Oncolytic adenovirus mediated Survivin knockdown by RNA interference suppresses human colorectal carcinoma growth in vitro and in vivo. J. Exp. Clin. Cancer Res. $28: 81$.

Vucic D, Stennicke HR, Pisabarro MT, Salvesen GS, et al. (2000). ML-IAP, a novel inhibitor of apoptosis that is preferentially expressed in human melanomas. Curr. Biol. 10: 1359-1366.

Wang L, Zhang Q, Liu B, Han M, et al. (2008). Challenge and promise: roles for Livin in progression and therapy of cancer. Mol. Cancer Ther. 7: 3661-3669.

Wang R, Lin F, Wang X, Gao P, et al. (2008). Silencing Livin gene expression to inhibit proliferation and enhance chemosensitivity in tumor cells. Cancer Gene Ther. 15: 402-412.

Wang X, Xu J, Ju S, Ni H, et al. (2010). Livin gene plays a role in drug resistance of colon cancer cells. Clin. Biochem. 43: $655-660$

Yan B (2011). Research progress on Livin protein: an inhibitor of apoptosis. Mol. Cell Biochem. 357: 39-45.

Yuan B, Ran B, Wang S, Liu Z, et al. (2012). siRNA directed against Livin inhibits tumor growth and induces apoptosis in human glioma cells. J. Neurooncol. 107: 81-87.

Zamore PD (2001). RNA interference: listening to the sound of silence. Nat. Struct. Biol. 8: 746-750. 